JURNAL RESPIRASI

$J R$

Vol. 1 No. 1 Januari 2015

\title{
Hubungan antara Obesitas dengan Penurunan Fungsi Faal Paru pada Polisi Wanita di Polda Jawa Timur
}

\author{
Christina Hardono, Benjamin Palgunadi Margono
}

\begin{abstract}
Background: The prevalence of obesity is increasing in Indonesia, and there is evidence that obesity, in particular abdominal obesity as a marker of insulin resistance, is negatively associated with pulmonary function. The mechanism for this association and the best marker of abdominal adiposity in relation to pulmonary function is not known. Study objectives: We assessed the association between pulmonary function (ie, FEVI and FVC) [with maneuvers performed in the sitting position] with adiposity markers (ie, body mass index (BMI) and waist circumference (WC), as markers of adiposity and body fat distribution in Policewomen in East Java Police Departement. We used paired student t test to analyze the association of pulmonary function and abdominal adiposity markers. Design: Observational cross sectional analytic study. Setting and participants: A random sample of policewomen $(n=120)$ from the general population East Java Police Departement, 20 to 45 years of age, who fulfill inclusion criterion of this study. Results: The measures of adiposity (ie. Waist circumference and BMI) were not significantly related to \%FEVI and \%FVC after analyzed with correlation Pearson and Spearman test ( $p>0.05)$. Conclusion: BMI categories and waist circumference (WC) were not associated with FEVI percent predicted and FVC percent predicted, may be the physical activity twice a week can maintain health status.
\end{abstract}

Key words: Body mass index, Waist circumference, Pulmonary function

\section{PENDAHULUAN}

Angka prevalensi berat badan lebih dan obesitas meningkat di seluruh dunia. Epidemik obesitas tidak hanya melanda US (United State) tetapi juga mendunia, termasuk negara berkembang. Suatu perbandingan data dari tahun 1976-1980 dengan tahun 1999-2000 memperlihatkan bahwa prevalensi berat badan lebih (BMI: $25-29.9 \mathrm{~kg} / \mathrm{m}^{2}$ ) meningkat dari $46 \%$ menjadi $64.5 \%$, dan prevalensi obesitas $\left(\mathrm{BMI} \geq 30 \mathrm{~kg} / \mathrm{m}^{2}\right.$ ) meningkat dua kali dari $30.5 \%$. $^{1,2}$

Hasil survei kesehatan terhadap lebih dari 2.000 polisi dan karyawan di kantor polisi Toronto memperlihatkan bahwa hampir 2/3 dengan berat badan berlebih. Hampir $90 \%$ responden mengakui bahwa mereka mempunyai kebiasaan makan makanan yang kurang sehat dan $65 \%$ dengan berat badan lebih, $20 \%$ terdiagnosa sebagai obesitas. ${ }^{3}$

Prevalensi kegemukan di Indonesia relatif tinggi. Penelitian Kodyat dkk. (1996) terhadap 10.459 orang umur 18 tahun ke atas di 12 kotamadya di Indonesia pada tahun 1996 menunjukkan bahwa yang menderita kegemukan sebanyak 22,5\%, yang $54,2 \%$ di antaranya menderita kegemukan tingkat berat (obesitas). Bila dilihat menurut jenis kelamin, ternyata perempuan sebesar $26,1 \%$ dan laki-laki 15,7\%. Bila dilihat menurut jenis pekerjaan, pegawai negeri sipil (PNS) sebesar 27,3\% termasuk gemuk. ABRI (dulu belum dipisah TNI dan Polisi) sebesar 26,4 di antaranya termasuk gemuk. Bila hanya dilihat kelompok umur, 41-55 tahun ternyata prevalensi gemuknya lebih tinggi, yaitu dari 2.586 orang sebesar $33,7 \%$, yang $59,0 \%$ di antaranya termasuk obesitas. ${ }^{4}$

Penurunan fungsi pernapasan dihubungkan dengan morbiditi dan mortaliti, memburuknya fungsi ini diduga terjadi pada semua kematian, yang sebagian besar kematian disebabkan oleh kanker, penyakit paru, penyakit kardiovaskular dan stroke., begitu pula dengan obesitas juga dihubungkan dengan angka morbiditi dan mortaliti. Sejumlah penelitian telah dilaporkan adanya hubungan terbalik antara fungsi pernapasan dan berbagai penanda obesitas atau distribusi lemak. ${ }^{5,7}$ Obesitas menyebabkan penurunan volume paru dan peningkatan tahanan jalan napas, yang dapat menimbulkan gejala mirip asma.

Penanda ini termasuk pengukuran keseluruhan adipositi, seperti berat badan atau BMI (body mass index (berat badan $(\mathrm{kg}) /$ tinggi $\left.(\mathrm{m})^{2}\right)$ dan pengukuran distribusi lemak, seperti lingkar perut (waist circumference), rasio lingkar perut 
dengan area permukaan tubuh atau tinggi, persentase massa lemak, dan ketebalan kulit.

Penelitian klinik telah melaporkan bahwa rasio lingkar perut dan lingkar pinggang, suatu pengukuran obesitas perut yang dihubungkan juga dengan menurunnya fungsi pernapasan pada obesitas yang ringan. ${ }^{5,6} \mathrm{Hal}$ ini mendorong untuk dilakukan penelitian dengan tujuan mengetahui apakah ada hubungan antara obesitas dengan penurunan fungsi faal paru pada polisi wanita di Polda Jatim.

\section{METODE PENELITIAN}

Penelitian ini dilakukan di Polda Jawa Timur. Sampel penelitian adalah polisi wanita yang berdinas di Polda Jawa Timur yang diambil secara random dari populasi dan memenuhi kriteria inklusi. Kriteria inklusi pada penelitian ini adalah polisi wanita yang berusia 20-45 tahun tidak merokok, tidak menderita asma, dan bersedia ikut penelitian dengan menandatangani Informed consen, sedangkan kriteria eksklusi pada penelitian ini adalah polisi wanita yang mempunyai riwayat penyakit paru yang dilihat dari data foto thorax (hasil rikkes berkala rutin yang diadakan Biddokkes Polda Jatim) dalam 1 tahun terakhir dan hamil.

Instrumen yang digunakan adalah Kuesioner: IUATLD questionnaire, ${ }^{23}$ Foto toraks, alat pengukur tinggi badan dan berat badan yang telah ditera terlebih dahulu, alat pengukur lingkar perut, alat hitung kalkulator serta autospirometri MINATO AS-500.

Data diolah secara manual dan disajikan dalam bentuk tabel/grafik, dengan uji statistik paired student $\mathrm{t}$ test mengingat variabel penelitian termasuk katagori numerik.

\section{HASIL PENELITIAN}

Penelitian ini dilakukan terhadap 150 polisi wanita, tetapi hanya 120 polisi wanita yang berdinas di Polda Jatim yang memenuhi kriteria penelitian. Pengumpulan data dilakukan selama 5 hari, bertempat di ruang aula Biddokkes (Bidang Kedokteran dan Kesehatan) Polda Jatim. Umur subjek penelitian berkisar antara 20-45 tahun dan sebagian besar berumur antara 39-45 tahun sebanyak 70 orang $(58,33 \%)$. BMI dilakukan klasifikasi menurut WHO. BMI di bawah 25 dan di atas 25 sama masing-masing 60 responden. Lingkar perut subjek penelitian sebagian besar dalam alerting zone (zona waspada) / action level 1) sebanyak 50 responden $(41,7 \%)$, diikuti action zone (zona aksi)/action level 2 sejumlah 47 responden (39,2\%). Dalam penelitian ini baik BMI maupun lingkar perut terdistribusi dalam semua kategori pada Tabel 1.

Hasil pengukuran faal paru ventilasi dibandingkan dengan standar. Rerata \%FVC adalah 94,75 \pm 11,12 dalam rentang antara 49 - 132. Subjek penelitian yang mempunyai $\% \mathrm{FVC} \leq 80$ sebanyak $8(6,7 \%)$ responden. Rerata \%FEV1
Tabel 1. Karakteristik Subjek Penelitian

\begin{tabular}{lcc}
\hline \multicolumn{1}{c}{ Variabel } & Frekuensi & Prosentase \\
\hline Umur (tahun) & & \\
$\quad \leq 28$ & 7 & 5,83 \\
$29-38$ & 43 & 35,83 \\
$39-45$ & 70 & 58,33 \\
& & \\
BMI (Kg/m2) & 3 & 2,5 \\
$\quad<18,5$ (Underweight) & 57 & 47,5 \\
$18,5-24,9$ (Normal weight) & 49 & 40,8 \\
$25,0-29,9$ (Overweight) & 11 & 9,2 \\
$\geq 30,0$ (Obese) & & \\
& & \\
Lingkar Perut (cm) & 23 & 19,1 \\
$\quad<80$ (Normal) & 50 & 41,7 \\
$\quad 80-88$ (alerting zone/Zona & & \\
waspada)/action level 1 & 47 & 39,2 \\
$\quad>88$ (action zone/zona aksi)/ & & \\
action level 2 & &
\end{tabular}

adalah $96,67 \pm 12,28$ dalam rentang antara 46-125. Subjek penelitian yang mempunyai $\% \mathrm{FEV} 1 \leq 75$ sebanyak $4(3,3 \%)$ responden. Pada penelitian ini hasil pengukuran faal paru mempunyai rentang yang lebar dan sebagian mengalami gangguan faal paru.

Semua variabel dilakukan uji normalitas menggunakan uji Kolmogorov Smirnov satu sampel sebelum dianalisis statistik. Hasil uji normalitas menunjukkan bahwa semua variabel berdistribusi normal kecuali BMI, sehingga uji korelasi faal paru dengan lingkar perut menggunakan uji korelasi Pearson. Uji korelasi Spearman digunakan untuk uji korelasi faal paru ventilasi dengan BMI, uji korelasi umur dengan BMI, WC serta uji korelasi BMI dengan WC. Uji korelasi dinyatakan mempunyai hubungan yang sangat kuat bila $r \geq 0,75$, mempunyai hubungan yang sedang jika $r \geq 0,50-<0,70$, dan hubungan lemah jika $r<0,30$.

Hasil uji korelasi Spearman antara BMI dengan umur didapatkan adanya hubungan yang bermakna (harga $\mathrm{p}<$ $0,05)$ dengan kuat hubungan sebesar 0,236. Demikian pula hasil uji korelasi Spearman untuk BMI dan WC (lingkar perut) menunjukkan ada hubungan yang bermakna (harga $\mathrm{p}$ $<0,05$ ) (lihat Gambar 1 dan Gambar 2).

Pada Gambar 3 didapatkan hasil uji korelasi Spearman antara WC (lingkar perut) dan umur menunjukkan tidak ada hubungan yang bermakna (harga $\mathrm{p}>0,05$ ). Demikian pula pada Gambar 4 didapatkan hasil uji korelasi Pearson antara \%FVC dengan \%FEV1 terdapat hubungan yang bermakna (harga $\mathrm{p}<0,05$ ) dengan kuat hubungan sebesar 0,864. makin tinggi \% FVC makin tinggi pula \%FEV1 dan sebaliknya.

Hasil uji korelasi Pearson antara faal paru ventilasi (\%FVC dan \%FEV1) dengan lingkar perut menunjukkan tidak ada hubungan yang bermakna (harga $\mathrm{p}>0,05$ ) 


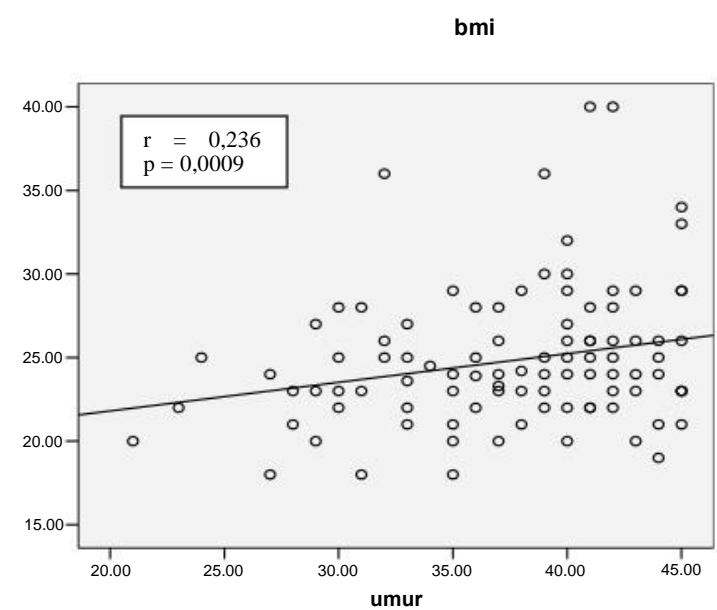

Gambar 1. Korelasi antara BMI dengan umur.

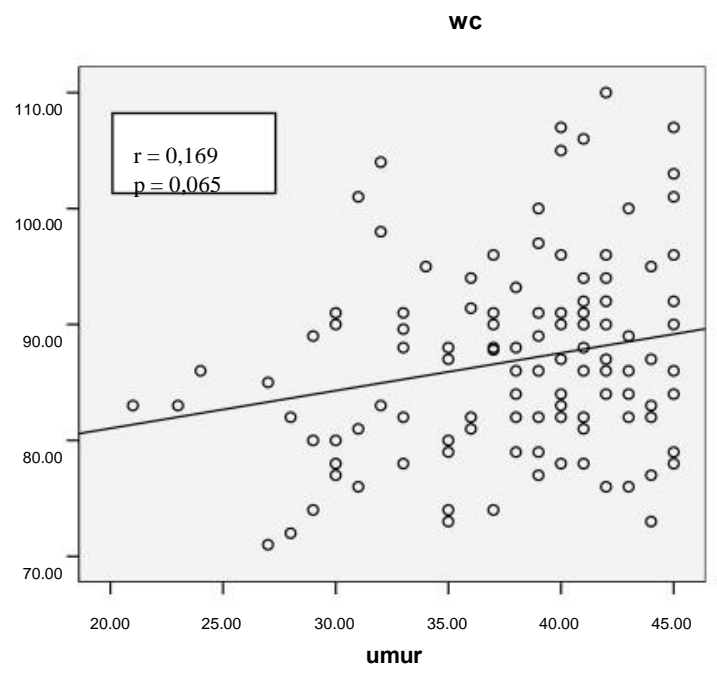

Gambar 3. Korelasi antara WC dengan umur.

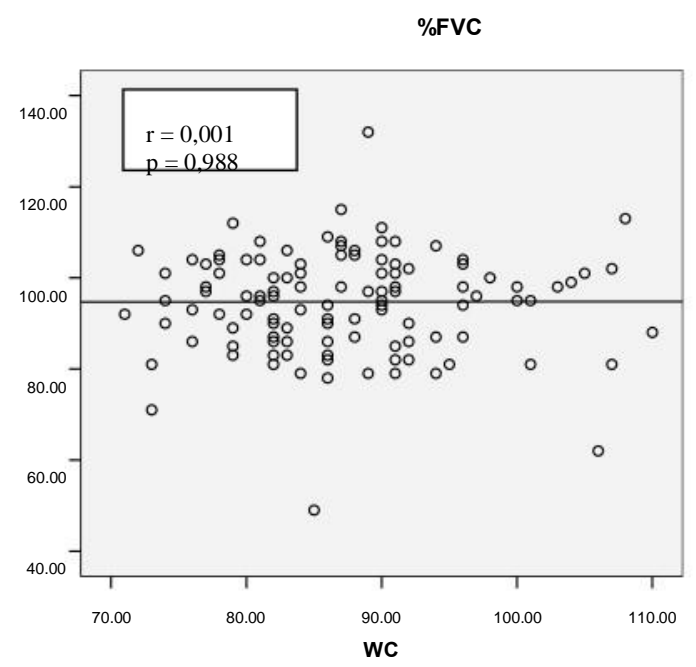

Gambar 5. Korelasi antara \% FVC dengan lingkar perut.

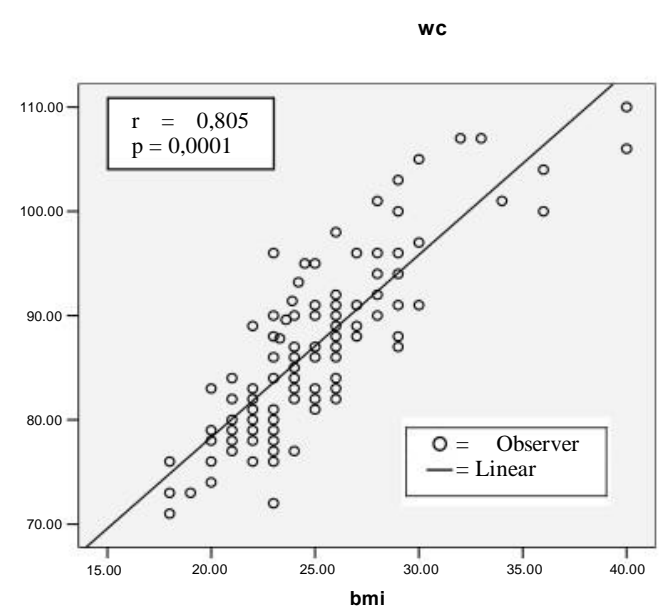

Gambar 2. Korelasi antara WC dengan BMI.

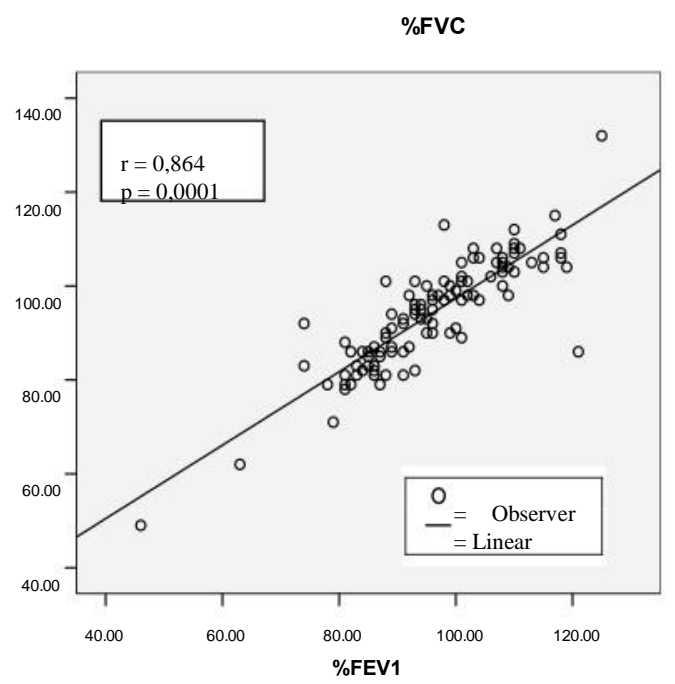

Gambar 4. Korelasi antara \% FVC dengan \% FEV1.

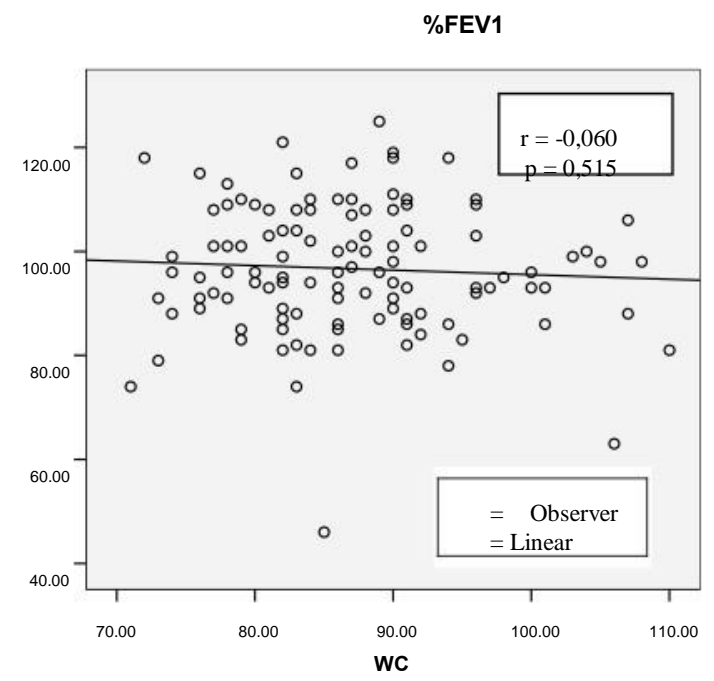

Gambar 6. Korelasi antara \% FEV1 dengan lingkar perut. 


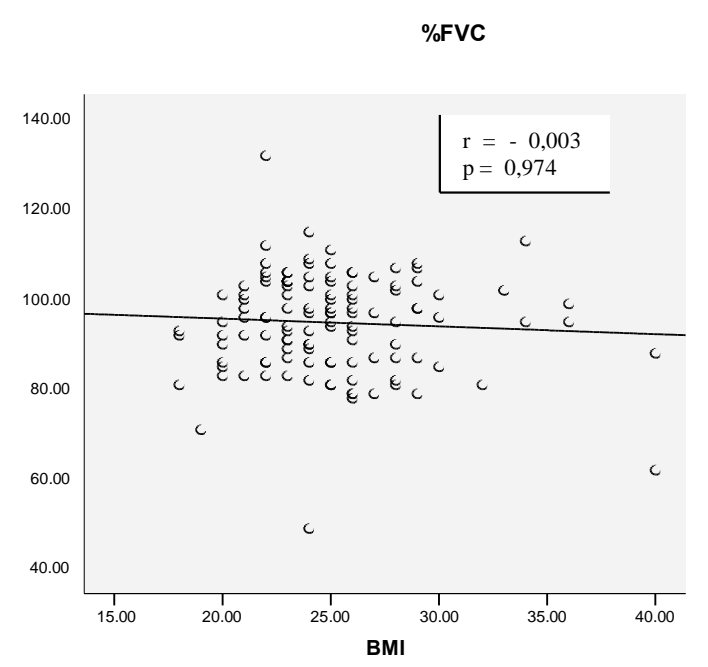

Gambar 7. Korelasi antara \% FVC dengan BMI.

(lihat Gambar 5 dan Gambar 6). Demikian pula hasil uji korelasi Spearman untuk faal paru antara \%FVC dan \%FEV1 dengan BMI pada Gambar 7 dan Gambar 8 tidak menunjukkan adanya hubungan yang bermakna (harga $\mathrm{p}>0,05)$.

\section{PEMBAHASAN}

Pada subjek penelitian ini didapatkan umur terbanyak (39-45 tahun) sebanyak 70 orang $(58,33 \%)$, nilai BMI > 25 sebanyak 60 responden (50\%), juga didapatkan $97(80,9 \%)$ responden dengan lingkar perut/WC terletak pada action level 1 dan 2.

Bertambahnya umur dihubungkan dengan perubahan komposisi tubuh, setelah usia 20-30 tahun. Proses penuaan juga dihubungkan dengan redistribusi baik lemak tubuh dan FFM (fat free mass), terjadi peningkatan relatif lebih besar lemak intra abdominal dibanding lemak subkutan atau total lemak tubuh. ${ }^{24}$

Hasil pengukuran faal paru pada penelitian ini merupakan perbandingan antara subjek dengan prediktet. Subjek penelitian yang mempunyai $\% \mathrm{FVC} \leq 80$ sebanyak $8(6,7 \%)$ responden dan yang mempunyai $\% \mathrm{FEV} 1 \leq 75$ sebanyak $4(3,3 \%)$ responden.

Hasil uji korelasi Spearman antara BMI dengan umur didapatkan adanya hubungan yang bermakna (harga $\mathrm{p}<$ 0,05) dengan kuat hubungan sebesar 0,236.

Kepustakaan menyebutkan bahwa mekanisme penuaan meliputi primer dan sekunder. Primary aging terjadi kemunduran struktur fisik secara progresif dan fungsi biologi, sebagai contoh perubahan komposisi tubuh (penurunan densitas mineral tulang, penurunan massa otot, dan penumpukan lemak perut). Secondary aging terjadi kemunduran struktur dan fungsi organ melalui perantara penyakit atau lingkungan yang membahayakan dan faktor kebiasaan hidup. ${ }^{25}$

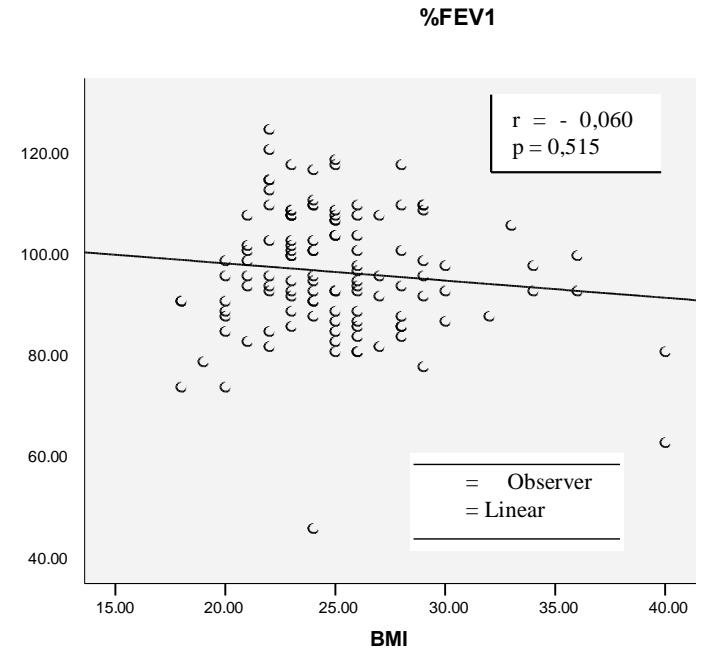

Gambar 8. Korelasi antara \%FEV1 dengan BMI.

Beberapa faktor yang menyebabkan terjadinya obesitas, oleh karena faktor genetik, metabolik, kebiasaan hidup dan lingkungan. Peningkatan prevalensi yang cukup tinggi pada obesitas memberi kesan bahwa pengaruh faktor kebiasaan hidup dan lingkungan lebih dominan dibanding dengan perubahan secara biologi. ${ }^{2,8}$

Demikian pula hasil uji korelasi Spearman untuk BMI dan WC (lingkar perut) menunjukkan ada hubungan yang bermakna (harga $\mathrm{p}<0,05$ ) dengan kuat hubungan sebesar 0,805. Penelitian Lean dkk, tahun 1995 tentang sensitiviti (> 97,5\%) dan spesifisiti (> 96.0\%) action levels dari WC/ waist circumference, action level 1: laki-laki: $94-102 \mathrm{~cm}$, wanita: $80-88 \mathrm{~cm}$ ) atau action level 2: laki-laki: $>102 \mathrm{~cm}$, wanita: $>88 \mathrm{~cm}$ untuk mengetahui subjek dengan nilai BMI $>25$ atau > 30. ${ }^{26}$ Hasil uji korelasi Spearman antara WC (lingkar perut) dan umur menunjukkan tidak ada hubungan yang bermakna (harga $\mathrm{p}>0,05$ ). Hal ini memberikan hasil yang sama dengan penelitian yang dilakukan oleh Kuk dkk, $2005(\mathrm{p}>0,05){ }^{28}$

Hasil uji korelasi Pearson antara faal \%FVC dengan $\%$ FEV1 didapatkan adanya hubungan yang bermakna (harga $\mathrm{p}<0,05$ ) dengan kuat hubungan sebesar 0,864. makin tinggi $\%$ FVC makin tinggi pula \%FEV1 dan sebaliknya. Hasil uji korelasi Pearson antara \%FVC dan \%FEV1 dengan lingkar perut menunjukkan tidak ada hubungan yang bermakna (harga $\mathrm{p}>0,05$. Demikian pula hasil uji korelasi Spearman untuk \%FVC dan \%FEV1 dengan BMI menunjukkan tidak ada hubungan yang bermakna (harga $\mathrm{p}>0,05$.

Kekuatan otot-otot pernapasan mungkin menurun pada obesitas, hal ini dihubungkan dengan akumulasi lemak perut dan dada sehingga terjadi peningkatan tahanan pernapasan dan saluran napas yang signifikan searah dengan tingkat kegemukan seseorang, dan menurunkan forced expiratory volume in one second (FEV1), forced vital capacity (FVC), kapasitas paru total (total lung capacity), kapasitas residu fungsional (functional residual capacity) dan volume cadangan ekspirasi (ERV=expiratory reserve 
volume). (Watson, Pride, 2005; Poulain et al, 2006; Chen, Rennie, Cormier, dan Dosman, 2007). ${ }^{16,17,18}$

Komposisi tubuh membagi massa tubuh menjadi 2 bagian: fat mass/massa lemak, terdiri dari keseluruhan lemak di dalam tubuh, fat-free (atau lean) mass (FFM), segala sesuatu selain lemak di dalam tubuh. Hal yang penting dari fat mass dan distribusi dari lemak tubuh telah diketahui berhubungan dengan penyakit kronis, termasuk penyakit kardiovaskuler dan abnormalitas dari toleransi glukosa (diabetes dan resistensi insulin). FFM dihubungkan dengan immune competence, status fungsional, dan survival. ${ }^{13}$

Penggunaan indeks kasar obesitas seperti BMI tidak dapat membedakan massa lemak dan FFM (fat free mass), sedangkan dalam beberapa tahun terakhir ini, faktor-faktor ini yang mempunyai efek berbeda terhadap fungsi paru. FFM (fat free mass)/LBM (lean body mass) diketahui mempunyai hubungan secara positif dengan fungsi faal paru (FVC), mungkin hal ini diperantarai oleh kekuatan otot, sedangkan FM (fat mass) mempunyai hubungan secara negative, dan adanya hubungan negatif ini oleh karena efek mekanik. ${ }^{19}$

Kepustakaan menyebutkan bahwa dengan melakukan aktivitas fisik rutin dapat meningkatkan komposisi tubuh (menurunkan perlemakan perut dan meningkatkan pengendalian berat badan). Paffenbarger dkk mengungkapkan bahwa aktivitas fisik rutin (mengeluarkan $>2000$ kcal per minggu dihubungkan dengan peningkatan rata-rata angka harapan hidup 1-2 tahun bagi umur 80 an. $^{28}$ Fakta menunjukkan bahwa kekuatan otot diafragma dan otot inspirasi meningkat pada latihan fisik. Adanya adaptasi otot-otot respirasi terhadap latihan fisik seluruh tubuh dapat mencegah terjadinya kelelahan diafragma. ${ }^{29}$

Penelitian Amsterdam Growth and Health Study selama 15 tahun menyebutkan bahwa aktivitas fisik berhubungan secara positif dengan perubahan FVC pada usia $13-27$ tahun. ${ }^{30}$ Penelitian yang dilakukan Pelkonen, dkk terhadap subyek penelitian melakukan aktivitas fisik jalan kaki dan bersepeda, pengeluaran energi lebih dari 2,268 kcal/minggu memperlihatkan dapat mengurangi terjadinya penurunan faal paru. ${ }^{31}$

Latihan fisik dapat mempengaruhi system kardiovaskuler, respirasi, endokrin, musculoskeletal, dan imun, yakni berpotensi mengurangi dan bahkan sebaliknya mencegah kemerosotan kardiovaskuler, metabolik dan muskuloskeletal oleh karena proses penuaan. ${ }^{32}$ Parameter fungsi paru cenderung mempunyai hubungan dengan kebiasaan hidup, seperti latihan fisik rutin dan tidak rutin. Berhubungan dengan latihan fisik rutin, atlit cenderung mempunyai kapasitas paru yang meningkat dibanding individu yang tidak melakukan latihan. ${ }^{33}$

Para anggota Polri pada umumnya termasuk polwan yang berdinas di Polda Jatim melaksanakan olah raga bersama yaitu senam kesegaran jasmani (aerobik) dan lari setiap hari selasa dan jumat (dua kali seminggu) yang sudah menjadi aturan tetap di kepolisian. Latihan fisik yang rutin ini akan dapat meningkatkan kekuatan otot diafragma dan otot-otot respirasi, sehingga hasil pemeriksaan faal paru retriksi pada anggota polwan tersebut tetap baik meskipun termasuk dalam kategori obesitas.

\section{KESIMPULAN}

1. Tidak ada hubungan antara faal paru ventilasi $(\% \mathrm{FVC}$ dan \%FEV1) dengan lingkar perut.

2. Tidak ada hubungan antara faal paru ventilasi $(\% \mathrm{FVC}$ dan \%FEV1) dengan BMI.

3. Pemeriksaan Faal paru ventilasi masih dalam batas normal dan tanpa dipengaruhi oleh obesitas, kemungkinan oleh karena latihan aerobik 2 hari dalam 1 minggu dapat menjaga kebugaran.

\section{DAFTAR PUSTAKA}

1. Haffner S, Taegtmeyer H. 2003. MINI-REVIEW: Expert Opinions: Epidemic Obesity and the Metabolic Syndrome. Circulation; 108: 1541-1545.

2. Malnick SDH, Knobler H. 2006. Reviews: The medical complications of obesity QJM; 99: 565-579.

3. Anonymous. (2006). Many Toronto Cops Are Overweight. http:// www.obesitydiscussion.com/forums [diakses 16 Desember 2008]

4. Anonymous. 2002. Artikel Medicastore. Ancaman kesehatan di balik kegemukan www.medicastore.com [diakses 16 Desember 2008]

5. Canoy D. 2004. Original Contributions: Abdominal Obesity and Respiratory Function in Men and Women in the EPIC-Norfolk Study, United Kingdom Am. J. Epidemiol. 159: 1140-1149.

6. Jones RL, Nzekwu MU. 2006. The Effects of Body Mass Index on Lung. Chest 2006; 130; 827-833.

7. King GG, et al. 2005. Original Articles: Respiratory Epidemiology: The Effects Of Body Weight On airway calibre Eur. Respir. J.; 25: 896-901.

8. LabibM. 2003. Reviews: The investigation and management of obesity. J. Clin. Pathol.; 56: 17-25.

9. Sekhri V, et al. 2007. Poster Presentations: Impact of Morbid Obesity on Pulmonary Function. Chest Meeting Abstracts ; 132: 613a-613.

10. Bottai M, et al. 2002. Longitudinal changes of body mass index, spirometry and diffusion in a general population. Eur Respir J 2002; 20: 665-673.

11. Chen Y, et al. 2005. Preliminary Report: Sex Specificity of Asthma Associated With Objectively Measured Body Mass Index and Waist Circumference: The Humboldt Study. Chest; 128: 3048-3054.

12. Balcom HMO, et al. 2006. Lung Function Testing: Pulmonary Function and Abdominal Adiposity in the General Population Chest; 129: 853-862.

13. Lazarus R, et al. 1998. Effects of body composition and fat distribution on ventilatory function in adults Am J Clin Nutr ; 68: 35-41.

14. Zavorsky GS. 2007. Lung Function Testing: Waist-to-Hip Ratio Is Associated With Pulmonary Gas Exchange in the Morbidly Obese. Chest ; 131: 362-367.

15. Alsagaff H, Mukti HA. 2002. Dasar-dasar Ilmu Penyakit Paru. Cetakan kedua Airlangga University Press, Surabaya.

16. Watson RA, Pride NB. 2005. Postural changes in lung volumes and respiratory resistance in subjects with obesity. J Appl Physiol, ; 98: 512-517.

17. Poulain M, et al. 2006. REVIEW: The effect of obesity on chronic respiratory diseases: pathophysiology and therapeutic strategies Can. Med. Assoc. J; 174: 1293-1299. 
18. Chen Y, Rennie D, Cormier Y, dan Dosman J. 2007. Obesity and eating disorder: Waist circumference is associated with pulmonary function in normal-weight, overweight, and obese subjects. Am. J. Clinical Nutrition, Jan; 85: 35-39.

19. Wannamethee SG, Shaper AG, Whincup PH. 2005. Nutritional Status, Dietary Intake, and Body composition: Body fat distribution, body composition, and respiratory function in elderly men. Am. J. Clinical Nutrition ; 82: 996-1003.

20. Sin D, Jones RL, Man SFP. 2002. Original Investigations: Obesity is a Risk Factor for Dyspnea but not for Airflow Obstruction. Arch Intern Med, Jul; 162: 1477-1481.

21. Light RW. 2000. Clinical pulmonary function testing, exercise testing and disability evaluation. In: George RB, Light RW, Mattay MA, Mayyhay RA (Eds). Chest medicine. Essential if pulmonary and critical care medicine. $4^{\text {th }}$ ed. Philadelphia. Lippincott William \& Wilkins. Hal. 91-117.

22. Pellegrino R, et al. 2005. Series: Interpretative strategies for lung function tests. Eur. Respir. J; 26: 948-968.

23. Bai J, Peat JK, Berry G, Marks GB, Woolcock AJ. 1998. Questionnaire Items That Predict Asthma and Other Respiratory Conditions in Adults. Chest 1998; 114; 1343-1348.

24. Villareal DT, et al. 2005. Obesity in older adults: technical review and position statement of the American Society for Nutrition and NAASO, The Obesity Society Am J Clin Nutr; 82: 923-34.

25. Fontana L, Klein S. 2007. Aging, Adiposity, and Calorie Restriction JAMA; 297(9): 986-994.
26. Lean MEJ, et al. 1995. Papers: Waist circumference action levels in the identification of cardiovascular risk factors: prevalence study in a random sample. BMJ; 311: 1401-1405.

27. Kuk JL, et al. 2005. Waist circumference and abdominal adipose tissue distribution: influence of age and sex. Am J Clin Nutr; 81: 1330-4.

28. Warburton DER, Nicol CW, Bredin SSD. 2006. Health benefits of physical activity: the evidence. CMAJ; 174(6): 801-9.

29. Babcock, et al. 1996. Aerobic fitness effects on exercise-induced lowfrequency diaphragm fatigue. John Rankin Laboratory of Pulmonary Medicine, University of Wisconsin, Madison, Wisconsin 53705. J Appl Physiol 81: 2156-2164.

30. Twisk JW, et al. 1998. Tracking of lung function parameters and the longitudinal relationship with lifestyle. Eur Respir J; 12: 627-634.

31. Pelkonen M, et al. 2003. Delaying Decline in Pulmonary Function with Physical Activity: A 25-Year Follow-up. Am J Respir Crit Care Med Vol. 168. pp. 494-499.

32. Lampman RM. 2002. Position Paper: The Importance of Physical Activity for Older Adults. Ed. Karen Petersmarck, Ph.D. Michigan Department of Community Published by the Michigan Fitness Foundation Director of Research, Department of Surgery St. Joseph Mercy Hospital.

33. Adegoke OA, Arogundade O. 2002. Original article: The Effect of Chronic Exercise on Lung Function and Basal Metabolic Rate in some Nigerian Athletes. Department of Physiology, College of Medicine, University of Lagos. P.M. B. 12003, Lagos African Journal of Biomedical. Research: Vol. 5; 9-11. 